\title{
Between a rock and a hard place
}

\author{
PJ Lombard GHD Pty Ltd, Australia
}

\begin{abstract}
Sharing in the closure and rehabilitation project challenges of a large open cast coal mine in South Africa from the initial stages to final closure can only be described as extremely rewarding. Watching draglines and dozers executing concurrent rehabilitation to the ultimate pleasure of witnessing rolling hills of grassland that are complimented by slopes covered in trees and shrubs through which contour berms flow and ebb guiding rainwater into energy dissipating gabion structures.

Void filling with draglines and dozers enhances the project timelines, however, the compaction and settlement of the spoil material and the subsequent placing of topsoil challenges the final design levels due to the variation in time of material settlement dependent on the initial depth of the final voids. The overall design criteria for mine closure is premised on the swift removal of surface flows during rain events in order to limit water ingress into the spoil material and in achieving this, limiting the erosion potential of these flows to a minimum.

The energy dissipating structures constructed as part of this design were fit for purpose, meaning that the structures will be stable and able to handle the design flow velocities on a continued basis without damage to the structures or uncontrolled erosion under, around or between the structures. Due to natural processes, erosion of the waterways (removal or deposition of sand/silt material) will take place between the structures. Fit for purpose will allow such natural processes to occur, provided it will be controlled and self-healing.

Design and implementation challenges will reveal themselves in the performance of the structures, and this will be subject to certain limitations, which can influence the performance, sustainability and service life of the structures. Performance criteria are based on the ability for all water management structures to be able to withstand the 1:100 year 24-hour return period runoff event without major damage.

The structures were designed and constructed in such a way that they will require low maintenance and are sustainable over the longer term. Low maintenance will mean that the structures will not require continued maintenance to keep them operating as intended. Maintenance will initially be higher than in subsequent years but limited to erosion control and vegetation maintenance. There should be a declining trend in maintenance requirements within the life expectancy of the materials used. Maintenance should not be more than what is envisaged during normal farming practices.
\end{abstract}

The project will include a maintenance period of 12 months starting from the date of practical completion of the structures.

Lessons learnt during this project will include design and construction improvements.

Keywords: energy dissipating gabion structures, settlement of material, design criteria, construction, maintenance requirements, erosion and performance

\section{Introduction}

The closure of a mine usually has a significant impact on the wellbeing of the community as highlighted by Grant et al. (2018). This impact is extreme in developing countries where local government lacks capacity to structure a development process that would provide alternative economic opportunities (World Bank 2002). The challenge for mine closure teams is to execute projects that will stand the test of time in terms of quality of delivery as well as reducing maintenance costs. The closure design should address these desirable outcomes within the stakeholder expectations of sustainable development opportunities as described by Narendranathan et al. (2012). 
Open cast mine voids extend over many hundreds and sometimes thousands of hectares. Sustainable final closure solutions for these mines are more than often grazing pastures for livestock. The success and longevity of the pastures are underpinned by limiting erosion and maintaining the health of the soil for as long as practicability possible.

Sustainable development practices on mine sites can be the mechanism by which capital generated through mineral extraction is passed on to future generations (Grant et al. 2018). The World Bank (2002) lists three sustainability development practice requirements:

1. Early constructive action by mining companies to ensure that the memory of mining is not one of negative environmental and social impacts-a reputation that will increasingly threaten future mining operations elsewhere.

2. The proactive involvement by local communities to ensure that the benefits from mining are sustainable for future generations.

3. The legal framework, with early planning and support to local communities by government, to ensure that the authorities are not left to manage large environmental and social legacies.

In 2003, the World Bank listed the elements of good mine closure planning (World Bank 2003). Mine planning should commence in the design phase and should contain at least the following elements:

- Times and costs.

- Specifics about the expected final landform and surface rehabilitation, including detoxification of dumps.

- Removal of plant related structures.

- Risk assessments to assist in prioritisation.

- Cost-benefit analysis of different options.

- Management plan for implementation of closure.

- Post-closure monitoring proposals.

In light of the abovementioned elements, it is noteworthy to mention that during the physical execution period of a closure project, the majority of time and cost spent would be in the void closure and final design shaping stages.

Void closures using draglines and dozers facilitates the concurrent rehabilitation process in terms of timelines, however the spoil material settlement takes place over time and this creates challenges for designers in terms of the inflow and outflow levels of structures to facilitate the expedient removal of surface water from the footprint of the mine (Figure 1).

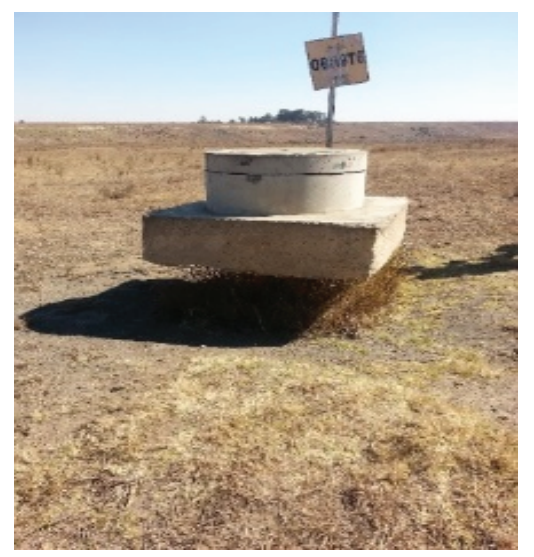

Figure 1 Borehole structure: evidence of void fill material settlement over time. $-500 \mathrm{~mm}$ over a five-year period 
The cost effectiveness of a closure project will be severely affected by poor designs and specifically steep slope designs that would challenge the practical implementation of the rehabilitation process as well as the sustainability thereof. "Quality water models and surface rehabilitation structure designs will optimise closure options" (Botha et al. 2018). Figure 2 is an example of a final design integrating the final void into the existing completed rehabilitation.

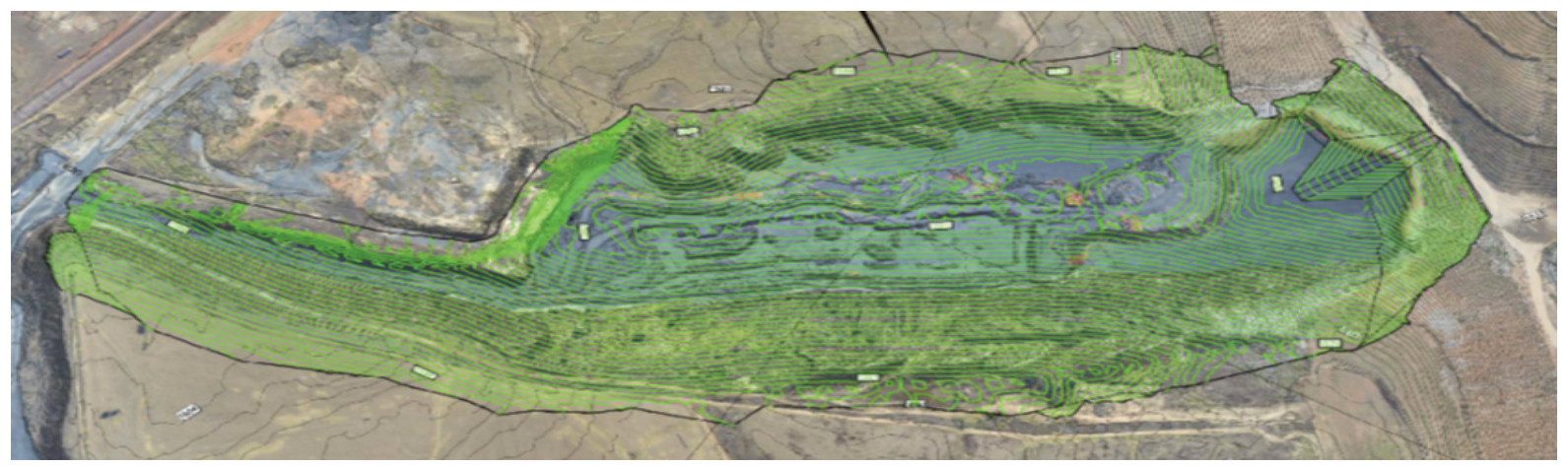

Figure 2 Final void closure design (courtesy Jones \& Wagener Services)

\section{The challenge: from design to construct}

\section{$2.1 \quad$ Objectives}

The objective of this project was to remove surface water flows from the mine surface area as soon as possible and in doing so reduce water ingress into the underground mine workings. The aim was to design and construct the water management structures in a rehabilitated open cast mine and to deliver a sustainable, low maintenance, water management system that will contribute to the sustainable closure criteria. The closure project phase of this mine started during the final operational stages. The rehabilitation and associated activities will continue for 5 to 10 years due to the size and complexity of the project. There is an underground section of mining that will become saturated with water that will ultimately decant as acid mine drainage, and this will need to be incorporated into the final surface flow designs.

\subsection{Performance criteria}

The structures to be constructed will have to adhere to specific performance criteria, which are the following:

- All water management structures will be able to withstand the 1:100 year 24-hour return period runoff event without major damage.

- All water management structures will be constructed to be fit for purpose.

- The overall design shall be constructed such that it will require low maintenance and is sustainable over the longer term until such a new natural state has been established 50 to 100 years and beyond.

\subsection{Limitations of the design}

The performance of the structures will be subject to certain limitations, which can influence the performance, sustainability and service life of the structures as follows:

- The design and performance of the structures are based on the assumption that all berms upstream from the structures are intact and operable. This means that water will be discharged at the outlets of these berms as intended prior to reaching the structures. Any breach in contour berms upstream of the structures could impact the performance of the structures negatively and this will have to be mitigated by ensuring all berms are well constructed and at the exact levels to ensure the effective delivery of flow volumes onto the structures. 
- The existing structures have been constructed with gabion baskets consisting of Galvan coated type material. This material was chosen as a result of the anticipated water quality, design life and as the result of discussions between the client, supplier and engineer. Cost implications played a role in the decision to use this material as well.

The other design and/or construction concerns that must be addressed are the following:

- Vegetation in and around structures.

- The level difference between structures.

- The size of the structures.

- Energy dissipation.

- The direction of water flow.

- The compaction of material during construction.

Performance of the system is very dependent on the vegetative cover of the disturbed areas. A contract was put in place with a local farmer to assist in establishing and maintaining the vegetation for a period in the normal way of good practice land management. This contract highlights the need to avoid over-grazing or destruction of vegetation due to road construction, ripping, re-grading, etc., and that this would cause the system to operate outside of the limits of its design intent, and failures due to such events will perpetuate ongoing remediation with the associated cost implications.

\subsection{Battery limits within the larger closure project}

The following battery limits were set for this project in order to differentiate the geotechnical aspects of the closure design work but also to ensure the seamless integration of this into the overall design aspects:

- Included are all the structures (gabion structures, side chutes and down chutes) in the areas mentioned under the scope of work.

- Included are the waterways between the structures up to the 1:100 year flood line plus $1 \mathrm{~m}$ freeboard.

- Included are the berms leading up to the structures for a distance of $20 \mathrm{~m}$ from the edge of the structures irrespective of the slope of the berm drains. This includes vegetation of a $20 \mathrm{~m}$ wide strip along the berm centreline as indicated in Figure 2.

- Included are the outlets of the berms discharging into the main drains for a distance of $20 \mathrm{~m}$ from the outlet point. Where the slope of the berm drains is steeper than 1:30 at the point $20 \mathrm{~m}$ from the outlet, then the battery limit will move further upstream to the point where the slope of the drain becomes 1:30.

- This includes vegetation of a $40 \mathrm{~m}$ wide strip along the berm centreline as indicated in Figures 3 and 4 indicating the extent of the vegetation in the flow channel of the structures. Included is making good of surfaces and vegetation of all areas previously vegetated and damaged by the construction works under this contract. Included is berm rectification for access roads constructed by the contractor under this contract. 


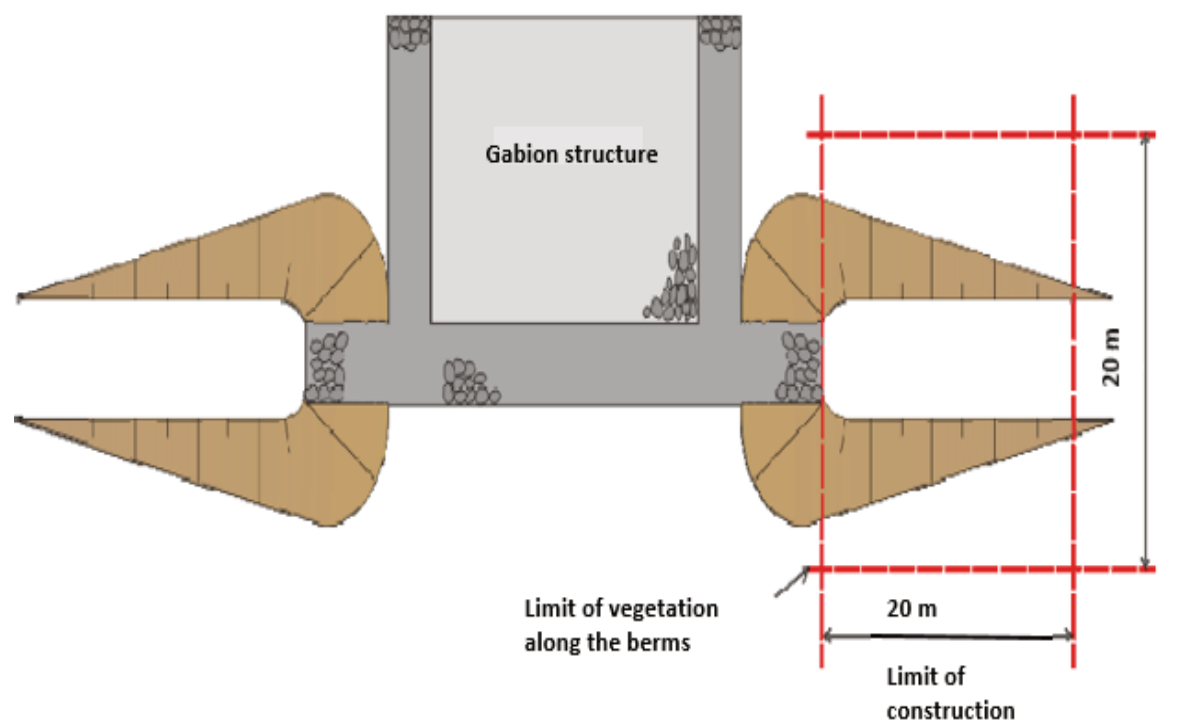

Figure 3 Limit of construction and vegetation criteria at gabion structures (courtesy Jones \& Wagener Services)

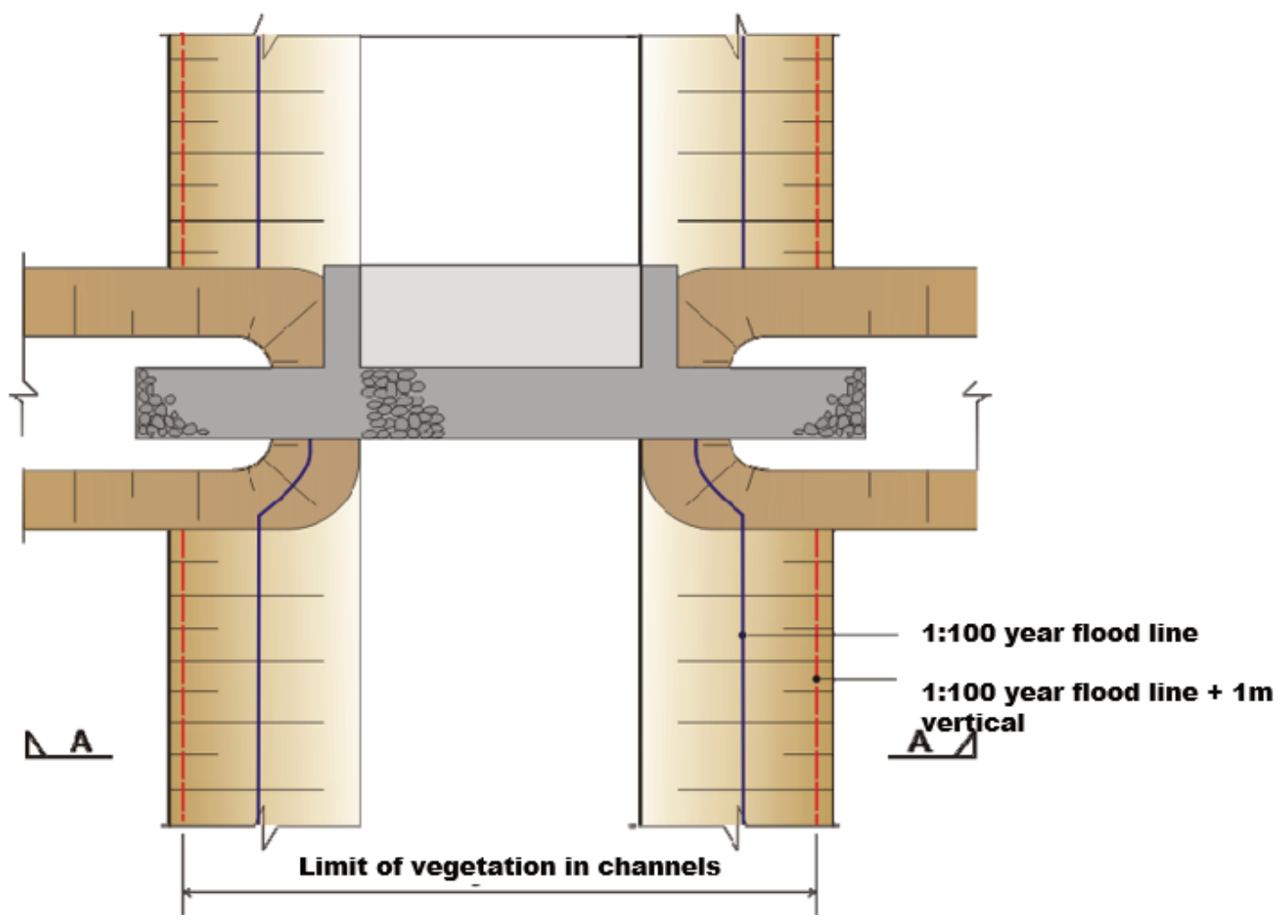

Figure 4 Limit of vegetation in the channels through the gabion structures (courtesy Jones \& Wagener Services)

\subsection{Maintenance period}

The design and construction of the water management structures need to be supported by a sufficient maintenance period in order to ensure the sustainability of the system.

The project will include a maintenance period of 12 months starting from the date of practical completion of the structures. Practical completion shall be determined by the engineer as the time where work is essentially completed and the structures are ready to receive the design flows. 


\section{$2.6 \quad$ Materials}

Materials for construction will be:

- Gabion and reno baskets, gabion and reno rock.

- Geotextile.

- Soil and grass (including fertiliser). Fertiliser will be applied at a rate of $300 \mathrm{~kg} / \mathrm{ha}$ of 2:3:2 and $150 \mathrm{~kg} / \mathrm{ha}$ of limestone ammonium nitrate unless otherwise specified by the soils specialist.

\subsection{Fit for purpose}

Fit for purpose will mean that the structures will be stable and able to handle the design flows on a continued basis without damage to the structures or uncontrolled erosion under, around or between the structures. Due to natural processes, erosion of the waterways (removal or deposition of sand/silt material) will take place between the structures. Fit for purpose will allow such natural processes to occur, provided it will be controlled and self-healing.

\subsection{Low maintenance}

Low maintenance will mean that the structures will not require continued maintenance to keep them operating as intended. Maintenance will initially be higher than in subsequent years but limited to erosion control and vegetation maintenance. There should be a declining trend in maintenance requirements within the life expectancy of the materials used. Maintenance should not be more than what is envisaged during normal farming practices.

Soil loss through erosion during peak flows especially while the cover plant material is still in the early stages of fulfilling their purpose will impede the performance of the structures until such time when an equilibrium have been reached with plant cover and effective water flows in the channels and through the structures.

Table 1 reflects the estimations of soil loss over a seven year test period at a specific gabion structure.

Table 1 Table example of soil loss estimates at a gabion structure (courtesy Jones \& Wagener Services). Estimates of soil loss for MU,s (0.066 ha). Soil erodibility is a rating where 7 is non-erodible and 1 very erodible. Slope steepness is in \% slope, slope length in metres, vegetal cover in

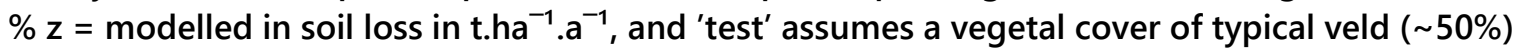

\begin{tabular}{lllllllll}
\hline $\begin{array}{l}\text { Gabion } \\
\text { Year }\end{array}$ & Erosivity & Soil & Slope & Slope & Vegetal & Slope & Cover & $\mathbf{Z}$ \\
\hline & $\mathrm{J} / \mathrm{m}^{2} / \mathrm{a}$ & Erodibility & Percent & Length & Cover & Factor & Factor & \\
Test 2001 & 9,000 & 4 & 1 & 50 & 50 & 0.35 & 0.06 & 0.3 \\
Test 2008 & 9,000 & 4 & 1 & 50 & 100 & 0.35 & 0.043 & 0.2 \\
\hline
\end{tabular}

\section{Constructability, durability and quality of all closure related infrastructure}

Post-mining regeneration priorities, in light of the country's developmental context, include restoration of land surface of a sufficient quality to support post-mining land use potential, restoration of the ecological function of mined land and in the case of previously degraded land, the ecological function must be improved.

Botha et al. (2018) mention the importance of slope design and the related follow-on effects of erosion that manifest during the site rehabilitation and closure stages challenge the design and construction teams in terms of durability and constructability. The legacy of slope selection during final design, as per Figure 5, of 
an open pit rehabilitation will have a significant effect on the risk profile of the final landform and more so in the introduced risks in rehabilitation activities. The closure planning and associated costing are highly influenced by the final design criteria.

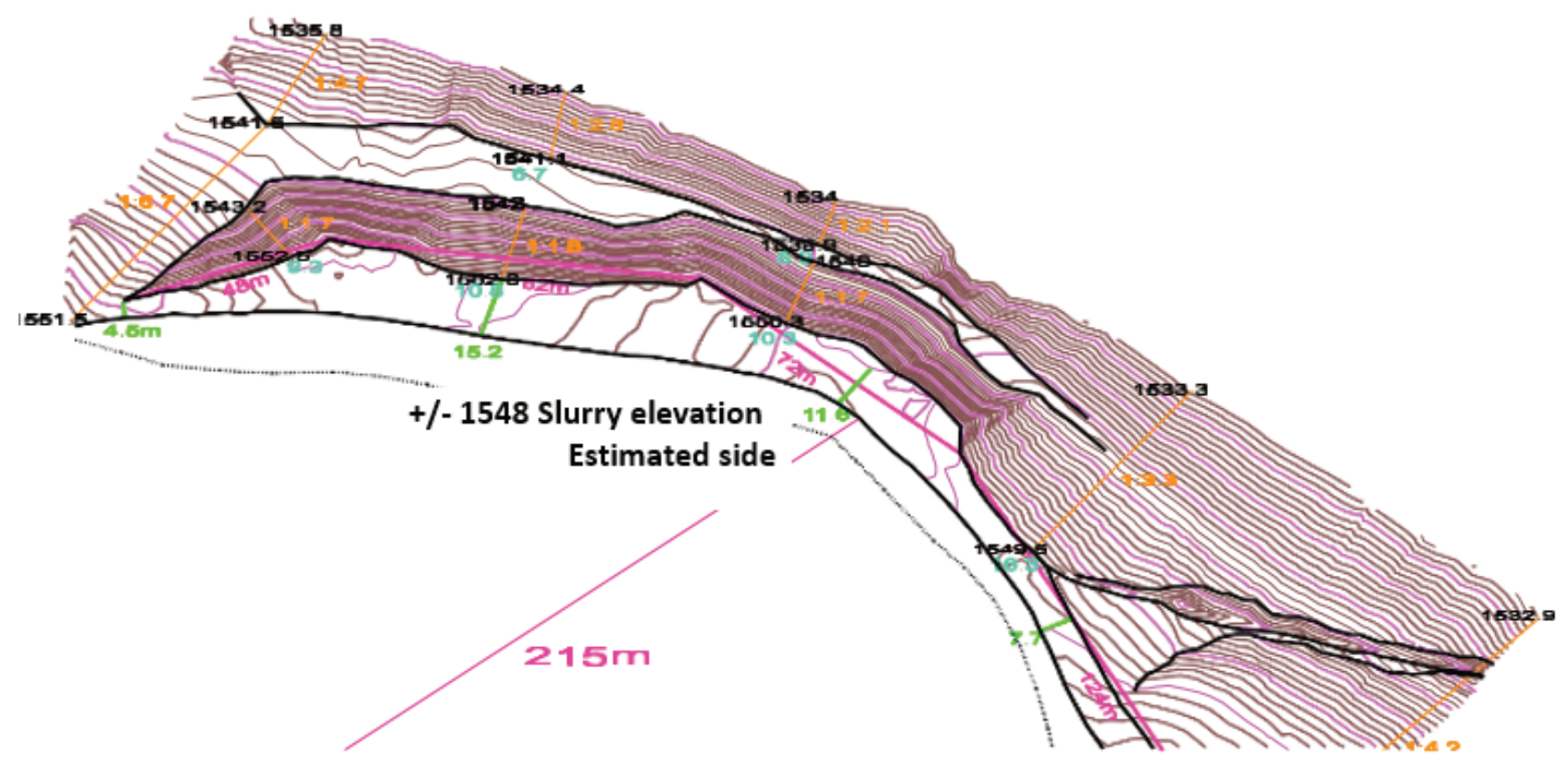

Figure 5 Detailed designs addressing steep slopes and gabion chute placements (courtesy Jones and Wagner Services)

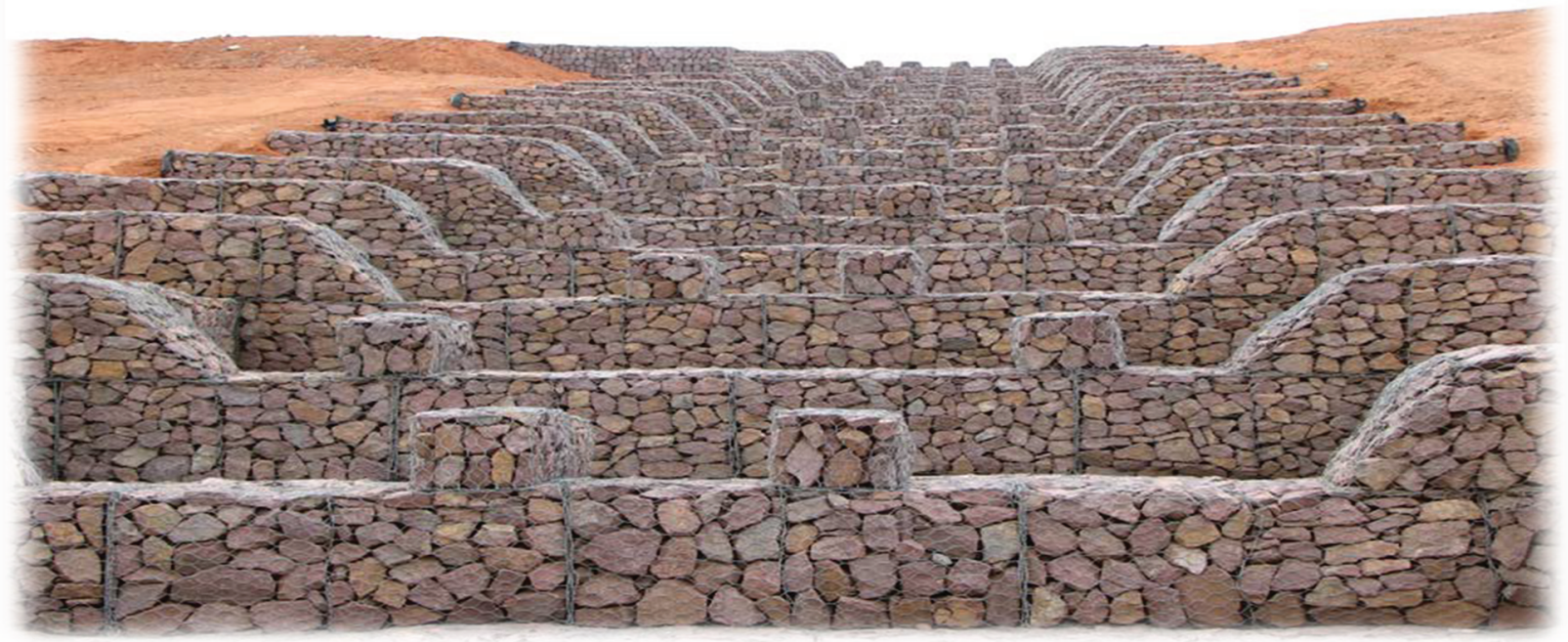

Figure 6 Recently completed gabion chute 2010

Slope angles largely influence the aspects of constructability, which in turn will guide durability and ultimately produce the quality of erosion control measures that will reduce future costs in aftercare and maintenance as can be seen in Figure 6 . Initial expenditure during concurrent rehabilitation will significantly reduce closure cost provisioning. The challenge is to convince mining production orientated operators of the benefits of concurrent rehabilitation and closure activities while still in the operational phase of the project. In instances where erosion control structures are being assessed and failures have occurred for various reasons, the remediation of post-closure erosion on slopes will most certainly damage the existing measures put in place to assist in slope stability. The regional environmental conditions determine the format of remediation, and where grasses and trees were re-introduced, potential damage to these areas will negate re-vegetation. 
Additional risks are re-introduced into the operation with people and equipment working in close proximity on steep slopes, especially where 1:5 and steeper slopes are involved. In conditions where acid mine drainage may occur, it is highly recommended that the construction of gabions and related structures be executed with the best materials available. Premature failures of construction material will prolong care and maintenance timelines and increase the risks and modelled costs. Failures will affect relinquishment timelines that in turn will affect costing and sustainability of the project.

\section{Construction: challenging design inadequacies}

\subsection{Construction sequencing}

The construction phase of large projects can stretch over months and sometimes even a year or more, and during this time rain events will highlight design inadequacies as well as poor construction sequencing of which the results can be seen in Figure 7. Significant failures will challenge the design and construction teams' relationship onsite.

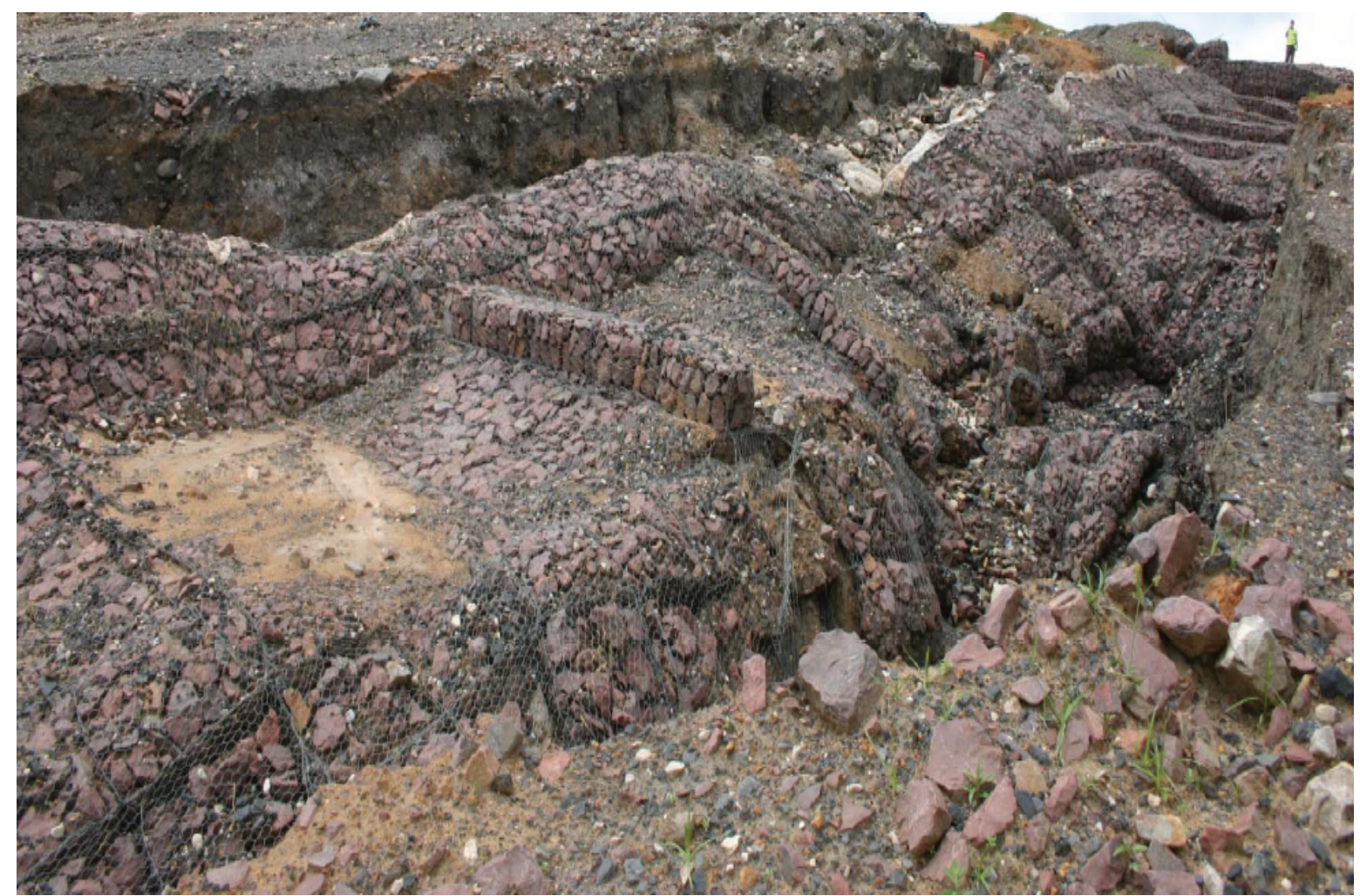

Figure 7 Failed structure after rain event of $90 \mathrm{~mm}$ in 30 minutes

The remediation process of significant failures are very time consuming and costly while re-introducing unnecessary risks to construction teams. The redesigned and constructed structure is shown in Figure 8. Additional energy dissipating baskets in the flow channel can be seen in Figure 8 . These baskets were not in the initial structure, as shown in Figure 9. 


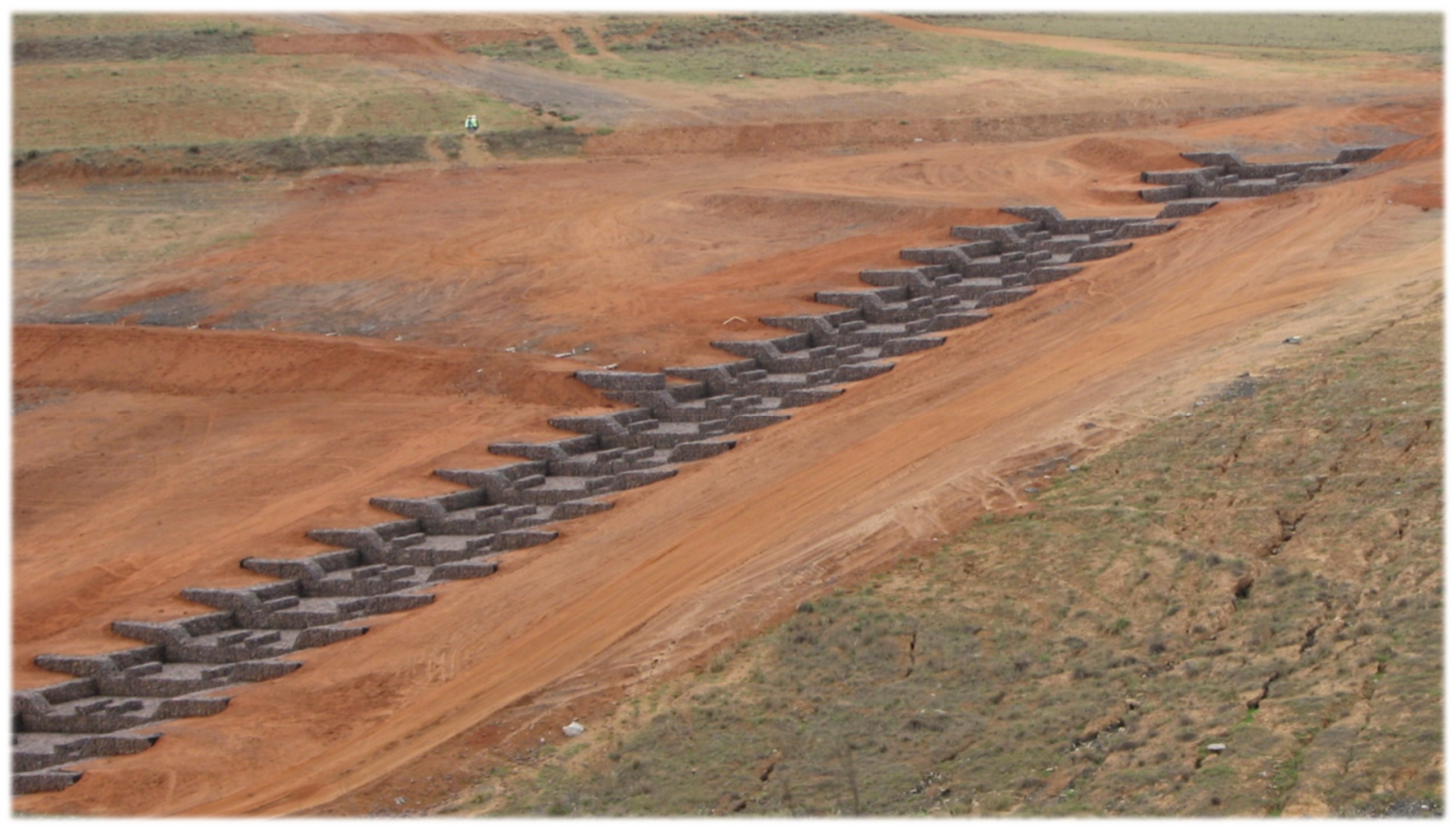

Figure 8 Re-design and re-constructed chute after failure of initial structure in Figure 9

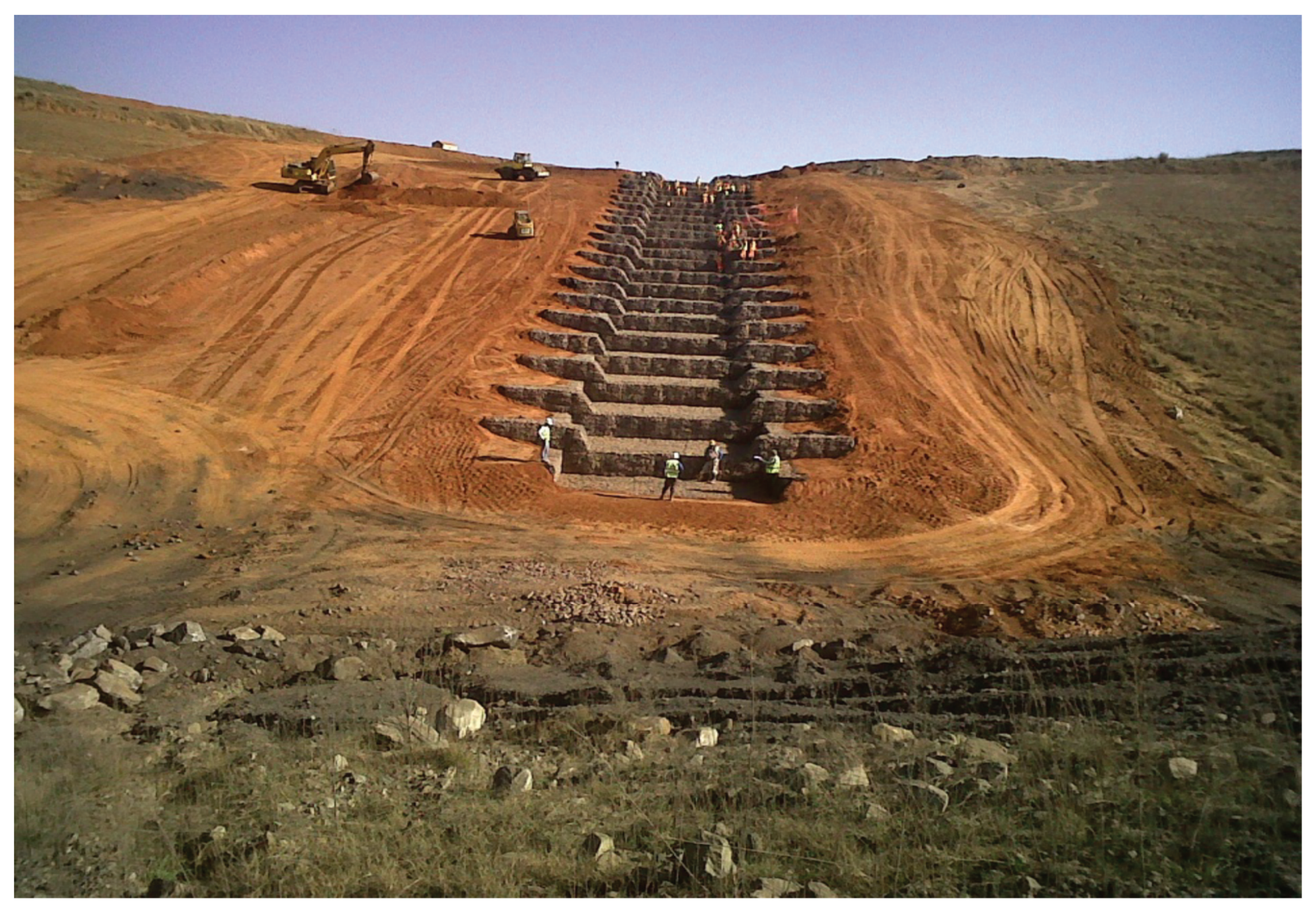

Figure 9 Completed chute structure before rain event of $90 \mathrm{~mm}$ in 30 minutes

\subsection{Energy dissipation}

Design calculations of velocities in the inflow channels are critical, and in a number of cases, the volume of water coming down the structures is so great that the rocks inside the baskets are displaced. This can be seen in Figures 10 and 11, showing the gabion structures are unable to absorb the water energy, and more energy 
dissipation is required to prevent damage to the baskets. If the energy is not dissipated, then the baskets may tear and be destroyed in time.

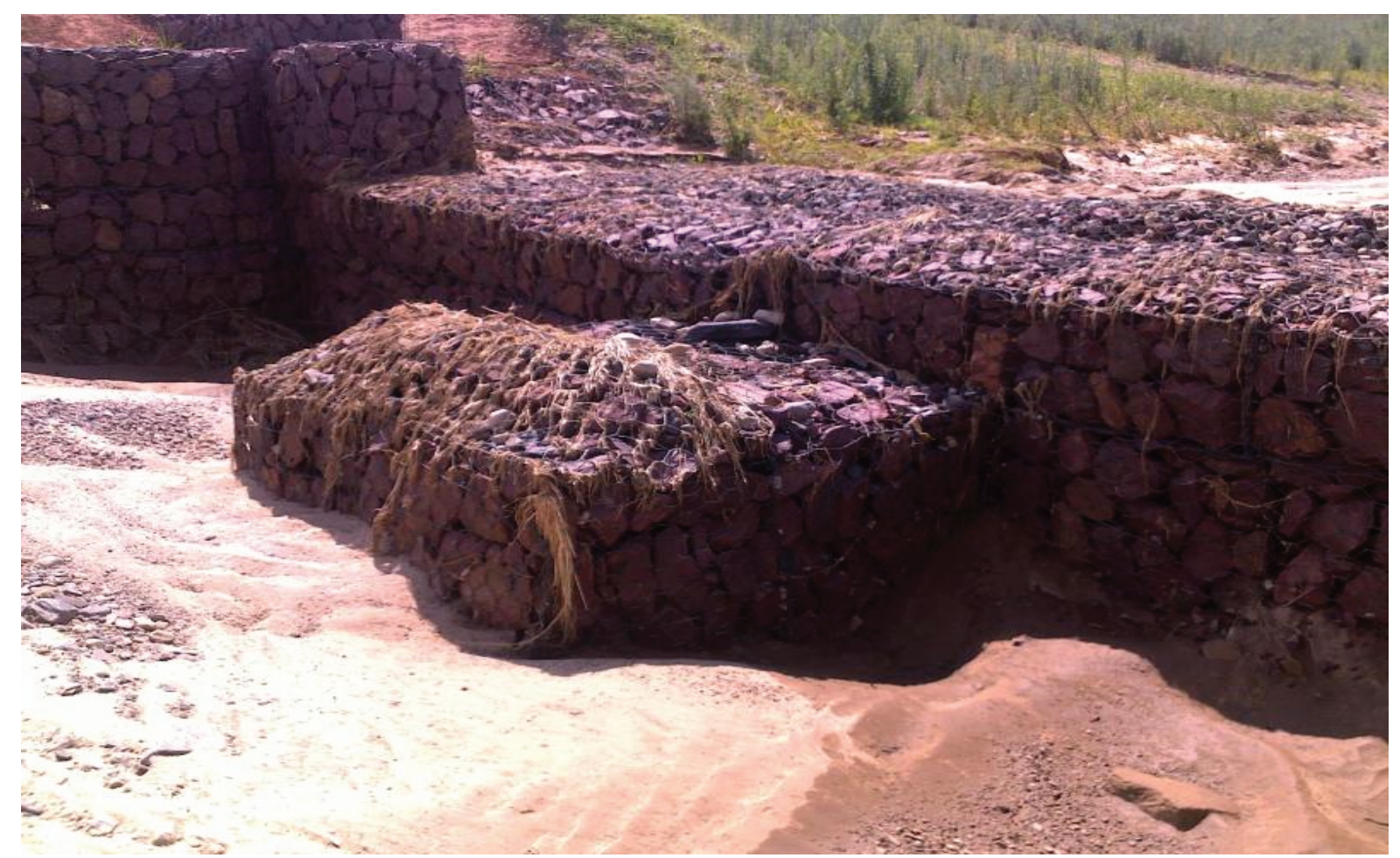

Figure 10 Displaced rocks-deforming structure

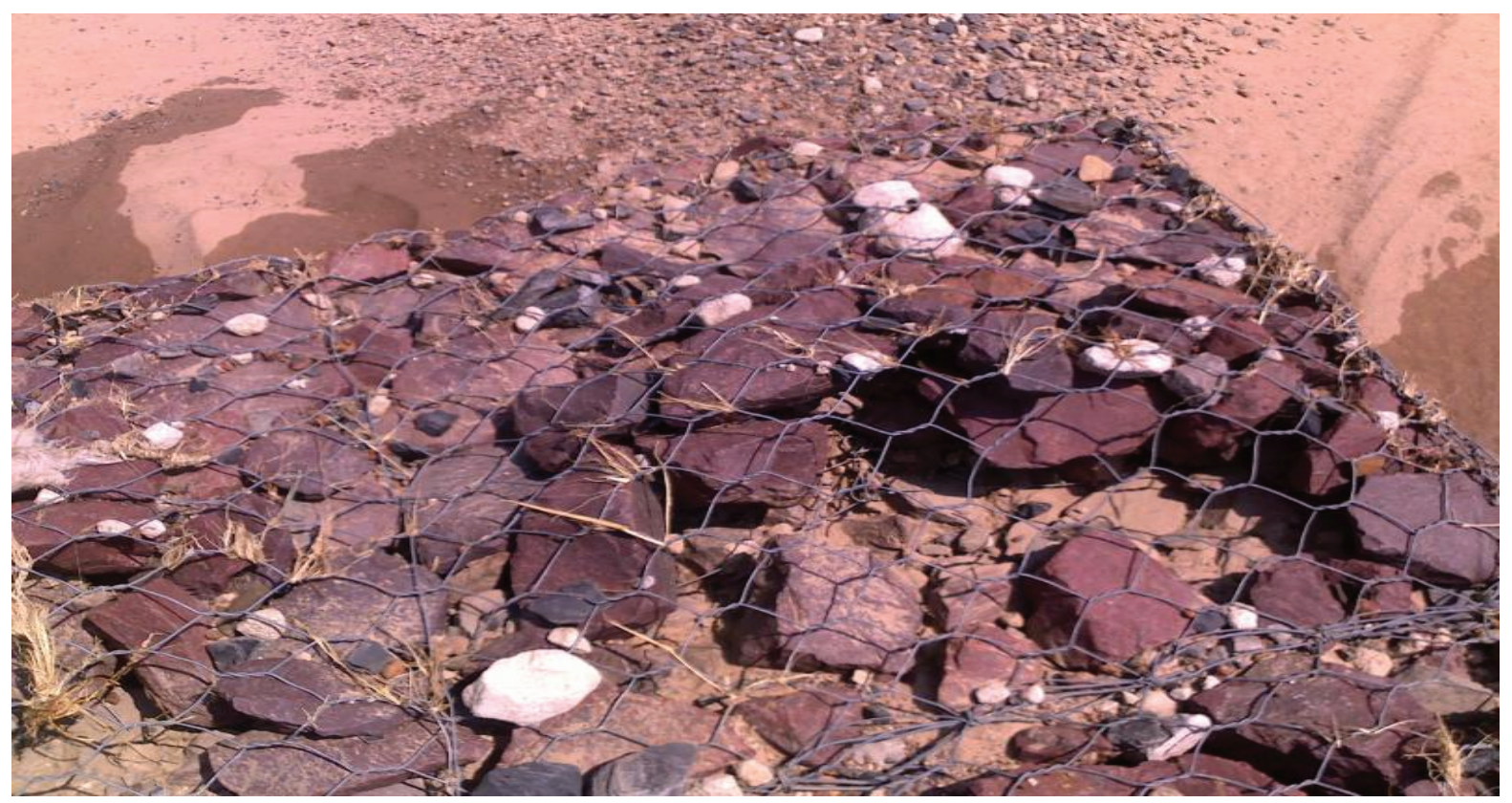

Figure 11 Rocks displaced in gabion basket

\subsection{Remediation}

The remediation of failed structures is very time consuming and costly. Contingencies in project planning very seldom allow sufficiently for significant budgetary overspend. The design and the construction team should conduct the complete assessment of failures in order to effectively remedy the failures. 
Accurate recordkeeping will be of value to all affected parties. The level of record keeping and the supplementary information will be critical in the diagnoses and solution stages of the remediation project. An example of this process is briefly covered in Table 2.

Table 2 Identification of structures requiring remedial work directly after initial failures during the first significant rain event (from PJ Lombard snag list; continued next page)

\begin{tabular}{|c|c|c|c|c|c|c|c|}
\hline Item & $\begin{array}{l}\text { Ramp } \\
\text { name } \\
\text { and } \\
\text { number }\end{array}$ & Contour berm and description & $\begin{array}{l}\text { Length } \\
\text { of } \\
\text { opening } \\
\text { (m) }\end{array}$ & $\begin{array}{l}\text { Berm } \\
\text { width } \\
\text { (m) }\end{array}$ & $\begin{array}{l}\text { Berm } \\
\text { height } \\
\text { (m) }\end{array}$ & $\begin{array}{l}\text { Volume } \\
\left(\mathrm{m}^{3}\right)\end{array}$ & $\begin{array}{l}\text { Surface } \\
\text { area } \\
\left(\mathrm{m}^{2}\right)\end{array}$ \\
\hline & E3A & & & & & & \\
\hline \multirow[t]{3}{*}{1} & & $\begin{array}{l}\text { From top of ramp going down, first } \\
\text { berm on the right hand side }\end{array}$ & 7 & 7 & 1.5 & 45.94 & 28 \\
\hline & & Sub total & & & & 45.94 & 28 \\
\hline & E3 & & & & & & \\
\hline 1 & & $\begin{array}{l}\text { First berm at the top where the road } \\
\text { leaves the parking area and going } \\
\text { downhill }\end{array}$ & 8 & 7 & 1 & 35 & 24 \\
\hline 2 & & Second berm from the top & 8 & 7 & 1.5 & 52.5 & 32 \\
\hline 3 & & Third berm from the top & 8 & 7 & 1.5 & 52.5 & 32 \\
\hline \multirow[t]{2}{*}{4} & & Forth berm from the top & 30 & 7 & 1.5 & 196.88 & 120 \\
\hline & & Sub total & & & & 336.88 & 208 \\
\hline & N1 & & & & & & \\
\hline \multirow[t]{3}{*}{1} & & $\begin{array}{l}\text { Berm before structure } 1 \text { on the left } \\
\text { hand side. Second berm uphill from } \\
\text { the stream bed }\end{array}$ & 10 & 10 & 15 & 93.75 & 40 \\
\hline & & Sub total & & & & 93.75 & 40 \\
\hline & N2 & & & & & & \\
\hline 1 & & $\begin{array}{l}\text { Berm to the right hand side of } \\
\text { Gabion \#1 }\end{array}$ & 5 & 7 & 1 & 21.875 & 15 \\
\hline 2 & & Berm to the left hand side of S1 & 20 & 7 & 1.5 & 131.25 & 80 \\
\hline 3 & & Berm to the left hand side of $\mathrm{S} 3$ & 6 & 7 & 1 & 26.25 & 18 \\
\hline 4 & & Berm to the left hand side of S6 & 6 & 7 & 1 & 26.25 & 18 \\
\hline 5 & & $\begin{array}{l}\text { Berm to the left hand side of S10 } \\
\text { (first } 3 \mathrm{~m} \text { drop structure) }\end{array}$ & 7 & 7 & 1 & 30.63 & 21 \\
\hline \multirow[t]{2}{*}{6} & & Berm to left hand side of Gabion \#6 & 7 & 7 & 1 & 30.63 & 21 \\
\hline & & Sub total & & & & 266.88 & 173 \\
\hline \multirow[b]{2}{*}{1} & N3 & & & & & & \\
\hline & & $\begin{array}{l}\text { Berm before chute } 1 \text { on left hand } \\
\text { side (next to fence) }\end{array}$ & 10 & 8 & 0.5 & 25 & 20 \\
\hline
\end{tabular}




\begin{tabular}{|c|c|c|c|c|c|c|c|}
\hline Item & $\begin{array}{l}\text { Ramp } \\
\text { name } \\
\text { and } \\
\text { number }\end{array}$ & Contour berm and description & $\begin{array}{l}\text { Length } \\
\text { of } \\
\text { opening } \\
\text { (m) }\end{array}$ & $\begin{array}{l}\text { Berm } \\
\text { width } \\
\text { (m) }\end{array}$ & $\begin{array}{l}\text { Berm } \\
\text { height } \\
\text { (m) }\end{array}$ & $\begin{array}{l}\text { Volume } \\
\left(\mathrm{m}^{3}\right)\end{array}$ & $\begin{array}{l}\text { Surface } \\
\text { area } \\
\left(\mathrm{m}^{2}\right)\end{array}$ \\
\hline 2 & & $\begin{array}{l}\text { First berm right hand side when } \\
\text { turning right at the gate going } \\
\text { downstream }\end{array}$ & 7 & 7 & 2 & 61.25 & 35 \\
\hline 3 & & $\begin{array}{l}\text { Second berm right hand side when } \\
\text { turning right at the gate going } \\
\text { downstream }\end{array}$ & 7 & 7 & 1.5 & 45.94 & 28 \\
\hline \multirow[t]{3}{*}{4} & & $\begin{array}{l}\text { Third berm right hand side when } \\
\text { turning right at the gate going } \\
\text { downstream }\end{array}$ & 7 & 7 & 1.5 & 45.94 & 28 \\
\hline & & Sub total & & & & 178.31 & 111 \\
\hline & $\begin{array}{l}\text { Still Box } \\
\text { East }\end{array}$ & & & & & & \\
\hline \multirow[t]{3}{*}{1} & & $\begin{array}{l}\text { First berm when entering the gate } \\
\text { from the top going downhill to } \\
\text { Gabion } 1\end{array}$ & 7 & 7 & 1.5 & 45.94 & 28 \\
\hline & & Sub total & & & & 45.94 & 28 \\
\hline & $\begin{array}{l}\text { Still Box } \\
\text { West }\end{array}$ & & & & & & \\
\hline 1 & & $\begin{array}{l}\text { First berm going down from the } \\
\text { railway to the ramp }\end{array}$ & 10 & 7 & 1 & 43.75 & 30 \\
\hline 2 & & $\begin{array}{l}\text { Berm on left hand side of GB1 (first } \\
\text { berm when entering the gate) }\end{array}$ & 22 & 7 & 2 & 192.5 & 110 \\
\hline \multirow[t]{2}{*}{3} & & $\begin{array}{l}\text { Berm on left hand side of GB10 (first } \\
\text { berm when entering the gate) }\end{array}$ & 10 & 6 & 2 & 75 & 50 \\
\hline & & Total & & & & $1,278.75$ & 778 \\
\hline
\end{tabular}

\subsubsection{Size of the structures}

Some structures are stopped too early as shown in Figures 12 and 13. The energy in the water is not yet dissipated and it causes high erosion at the end of the structure. Typically, if the end of the structure had a longer section of reno mattress, erosion may have been prevented. 


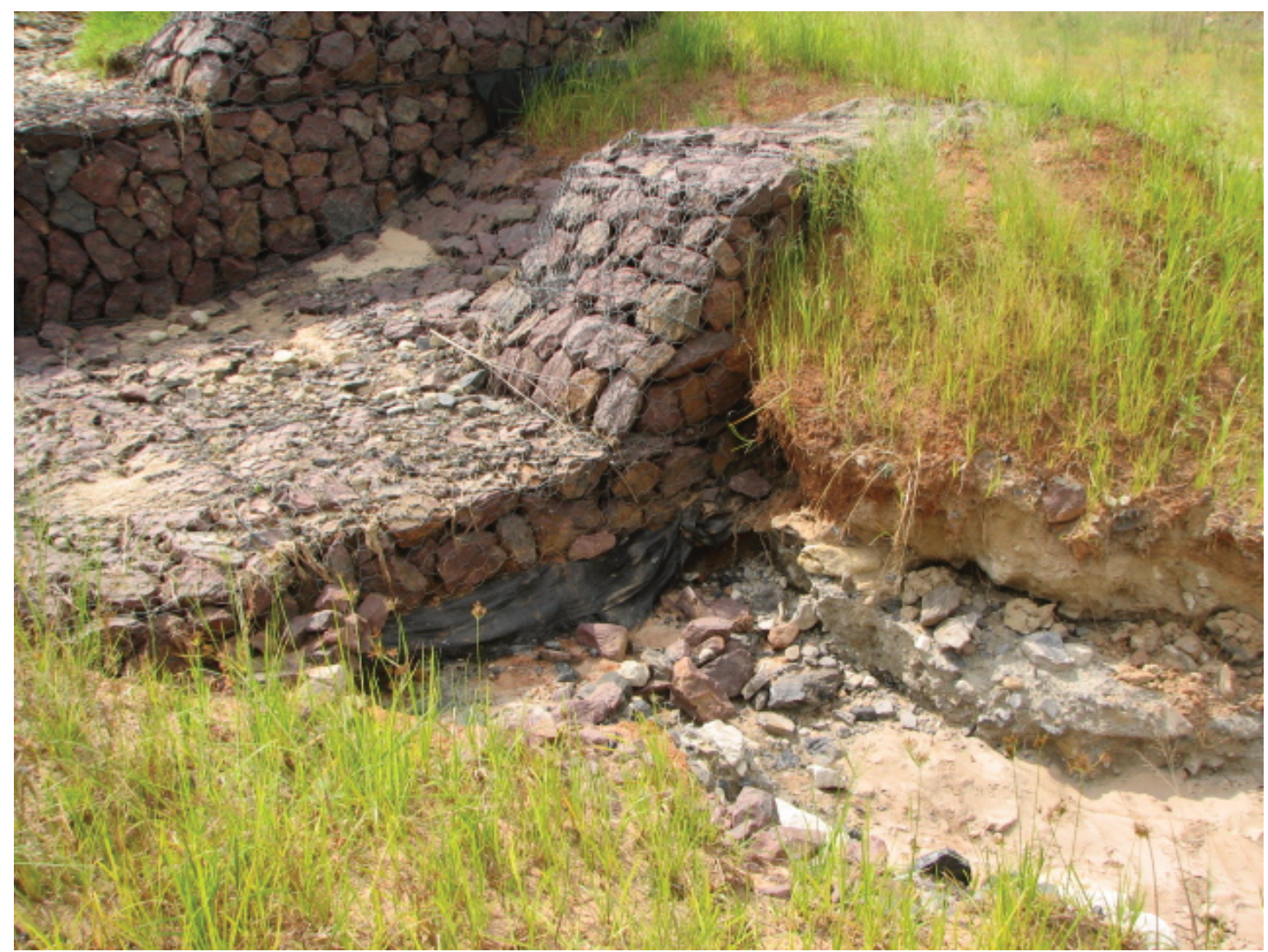

Figure 12 Size of structure inadequate (N1 1st Inlet photo IMG_0002 as per Table 2)

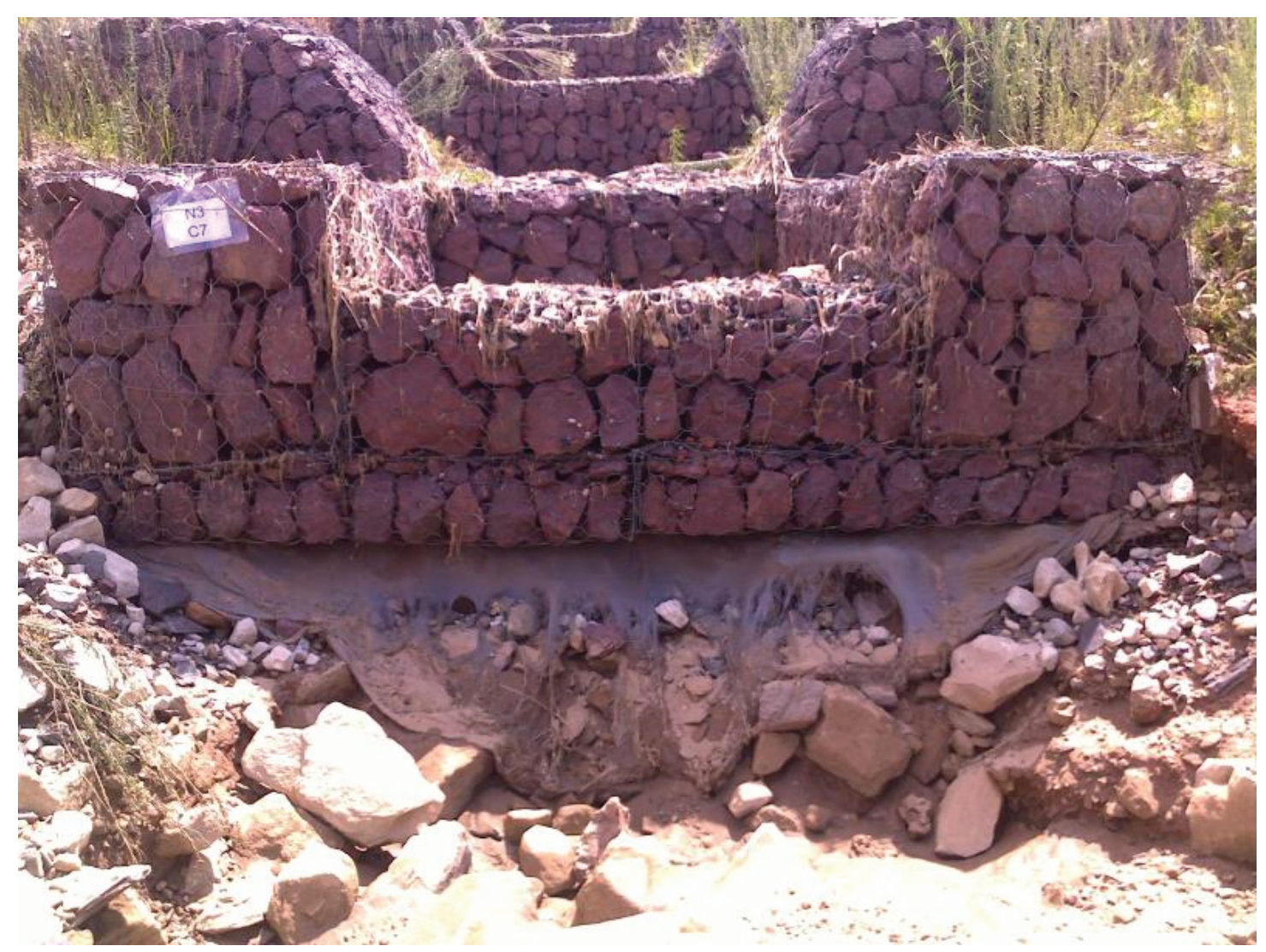

Figure 13 Size of structure (N3 C07 photo 002 as per Table 2) 
Furthermore, some structures-typically the last structure joining up with the final flow channel-stop too early and result in an incorrect bottom elevation where it terminates. This causes the following problems:

- Excessive erosion downstream of the structure, due to high energy dissipation of the water at the bottom of the drop, and possible failure of structure due to undermining effect of water concentrated flow paths.

- Therefore, higher velocities where the last structure is not low enough to join up with final water flow channel in the 'riverbed'. Examples are shown in Figures 12 and 13.

\section{$5 \quad$ Costing}

The cost of closure tends to be considerably lower in instances where the owner/operator of the mine conducts concurrent rehabilitation that leads into the closure and final process. The World Bank reported that significantly higher costs tend to be associated with state-run clean up due to the lack of familiarity with the site (World Bank 2002).

Cost estimation at the appropriate level of accuracy is critical. Most closure projects have a large component of uncertainty due to delayed intervals that often stems from change of ownership, and this may be underpinned by cost saving initiatives. A significant number of closure projects will be initiated from abandoned sites, with these scenarios highlighting the need for well-designed planning.

Early cost estimates are critical. Accurate, timeous estimates are necessary to ensure that sufficient funds are available towards the end of the mine's life. The estimates should be updated systematically every five years for a 30-year life-of-mine or every two years for a 10-year life-of-mine (World Bank 2002). Concurrent rehabilitation can save tens of millions of dollars in rehabilitation costs at closure.

The cost estimation for construction in projects as mentioned in the aforementioned project examples will be severely challenged due to inadequacies in design, as well as poor construction techniques and execution.

Most of the future closure projects will be funded through provisioning bonds and the like with clearly defined limitations for variations and even less room for failures and re-work. Concurrent rehabilitation has proven the significant cost saving benefits in many examples across the globe.

\section{Conclusion}

The timeline of rehabilitation related construction projects in large open cut mines may often extend over a number of years. Delivering projects through multiple rain seasons will challenge the construction sequence and techniques.

Effective communication between the client and the construction teams is invaluable. Risk assessments and monitoring of changing conditions should be entrenched in the work ethic on sites. Design shortcomings that present during the project need to be addressed at the earliest opportunity in order to minimise follow-on negative outcomes. The end state once construction is completed can be very rewarding and monitoring the performance of the structures during rain events is well pleasing.

Monitoring the structures in terms of stability will soon reveal the benefits of preventative measures rather that re-active costly re-work should minor failures present themselves. The prompt establishment of soil cover over the exposed areas will alleviate erosion impacts on the structures.

The mention of rewarding outcomes in the abstract is understated at the completion of a project of this nature. As soon as the bio-diversity returns and flourishes, the exponential seasonal improvement is often breathtaking. 


\section{References}

Botha, R, Muhlbauer, R \& Human J 2018, 'A stitch in time saves nine: a case study of the importance of quality water models and surface rehabilitation to optimize closure options', in C Drebenstedt, F von Bismarck, A Fourie \& M Tibbett (eds), Proceedings of the 12th International Conference on Mine Closure, TU Bergakademie, Leipzig, pp. 532-539.

Grant, C, Lacy, H, Ferguson, K \& Heyes, J 2018, 'Words, words, words: but what is the matter, my closure lords', in C Drebenstedt, Fvon Bismarck, A Fourie \& M Tibbett (eds), Proceedings of the 12th International Conference on Mine Closure, TU Bergakademie, Leipzig, pp. 15-22.

Narendranathan, S, Thomas, RDH, Bungard, GP, Gumba, V \& Barker, C 2012, 'The importance of collaboration between designers and contractors in implementing a design in challenging conditions', Proceedings of the Eighth AusIMM Open Pit Operators Conference, The Australasian Institute of Mining and Metallurgy, Melbourne.

World Bank 2002, It's not Over When it's Over: Mine Closure Around the World, World Bank Group's Mining Department, Washington. World Bank 2003, Elements of Good Mine Closure Planning, World Bank Group's Mining Department, Washington. 
